\title{
MECHANICAL SOWING ON SIUTABLE RIDGE SIDE
}

\author{
Ibrahim M. M. , Abd Alla H. El. ${ }^{* *}$, Lotfy A. E. ${ }^{* *}$ and Osman Y. K ${ }^{* * * *}$
}

\section{ABSTRACT}

A combined machine for ridging and sawing maize on suitable ridge side was developed. The experiments of this research were divided into two groups. The first group was done to study the influence of the developed former and the ridger in ridge construction. Four experimental factor were 1- tractor forward speed, $(\mathrm{m} / \mathrm{sec}) 2$ - ridger depth, $(\mathrm{cm}) 3$ - ridge former side angle, (degree) 4-former height, (cm) and two measurements were recorded there were 1- cross section area2- soil profile, the optimum cross section area was $673.44 \mathrm{~cm}^{2}$ and the best soil profile was gained at opener depth $9 \mathrm{~cm}$, forward speed $0.55 \mathrm{~m} / \mathrm{sec}$, ridge former side angle 60 degree and former height $-6 \mathrm{~cm}$. In the second experimental group two experimental factors were investigated there were 1- hill spacing 2- sowing depth and three measurements were recorded there were 1- longitudinal scattering, (C.V., \%) 2-lateral scattering, (\%) 3emergence, (\%).The lowest value of longitudinal scattering (C.V., \%), was $(21.26 \%)$ was obtained at theoretical hill spacing $28 \mathrm{~cm}$ and sawing depth $5 \mathrm{~cm}$. In general data showed that Increasing sawing depth and hill spacing tend to decrease in the lateral scattering. Emergence \% increased with increasing sowing depth and hill spacing.

\section{INTRODUCTION}

7 Maize (Zia maize) is one of the main crops in Egypt. Harvested area (Faddan) equal to 2,305,997.6 It's production 1 (Ton) equal to $16,757,818$. In the World Harvested area (Faddan) equal to $161,908,449$. It's production (Ton) equal to $844,405,181$ (FAO, 2010). Planters are used to sow seeds under the soil surface. The main functions of any planter or seed drill are to: Open furrows in the soil to the proper depth; Meter the seed; Place the seed in the furrow; Cover the seed and compact the soil around the seed.

Prof. Agric., Fac. Agric. Mansoura Univ.

Head research, Agric. Eng. Research., Inst (AEnRI), El-Giza, Egypt.

*** Demonstrator, Power and machinery Dept., Fac. of Agric. Eng., Al-Azhar Univ. 
Sohne et al (1962) measured the cross section area by the following equation: $\mathrm{A}=\frac{\Delta L}{2}(\mathrm{a}+2 \mathrm{~b})$

Where: $\mathrm{A}=$ Total cross section area, $\mathrm{cm} 2$

$\Delta L=$ Constant horizontal distance between two adjacent ordinates , $\mathrm{cm}$

$\mathrm{a}=$ Sum of first and last ordinates, $\mathrm{cm}$.

$\mathrm{b}=$ Sum of all ordinates excluding the first and last ones, $\mathrm{cm}$.

Dowell et al. (1988) conducted a study with sweeps and found that the ridge height and the lateral distance increased with increasing travel speed.

Sharifat and Kushwaha (1999) studied soil lateral movement under different soil conditions with a sweep and a furrow opener at speeds from 5 to $8 \mathrm{~km} / \mathrm{h}$, and they concluded that different tools created different geometries of soil profiles; the parameters of soil profile were also affected by tillage speed, soil bulk density, and soil moisture content. They proposed an index of lateral soil movement, but no mathematical models were developed.

Marey S.A. et al. (2008) modificated sugar beet planter row spacing from $60 \mathrm{~cm}$ to $50 \mathrm{~cm}$ comparing with $40-60 \mathrm{~cm}$ row space (double furrows) using three different geometric shapes of opener with four levels of planting speed. The effect of study parameter were evaluated in terms of number of plants per feddan, seed scattering, root and sugar yield and water use efficiency. Increasing the forward speed from 2.25 to $7.4 \mathrm{~km} / \mathrm{h}$ tends to increase longitudinal, transverse scattering.

There for the objective of this study were to design a planter for ridging and sowing grains on suitable ridge side and proper with small farms. To make planters in local workshop by using conventional tools. To compare the costs of planting operation by the developed planter and by manual method. 


\section{MATERIAL AND METHODS}

This study was carried out to investigate the performance and operating parameters of a developed machine. The experiments of this research were divided into two groups conducted in the field. The first experimental group contents of four engineering parameters they were [Forward speed (S), Ridge former side angle (A), ridger depth (D) and former height $(\mathrm{H})$ ]. From the other side the obtained ridge profile and its area were recorded as experimental measurements, to define the optimum engineering parameters levels which taken as a constant fundamental base during carry out the second experimental group.

The second group contents two experimental parameters they were [theoretical hill spacing (h) and sowing depth (d)] in the other hand there were four experimental measurements were taken to evaluate the developed machine they were (hills longitudinal scattering, plants lateral scattering around the planting row centerline, fuel consumption and emergence percentage). Machinery costs were investigated also.

\section{3-1: Used Equipments and Machineries:-}

3-1-1: The tractor:- A Japanese (Yanmar $42 \mathrm{hp}$. 4WD ) was used in seedbed preparation and field experiments.

3-1-2: Chisel plough:- To prepare seedbed at a depth of $15 \mathrm{~cm}$, the local seven shanks chisel plough with seven shares $50 \mathrm{~cm}$ spacing arranged in two rows was employed. The tillage systems used in the present study were; the chisel plough two passes followed by the local budger .

3-1-3: A local budger (zahhafa):- A wooden leveler (zahhafa) of $200 \mathrm{~kg}$ weight with $300 \mathrm{~cm}$ working width was used three passes after chiseling to sweep and compact the tilled soil partially.

3-1-4: Components of the developed machine:- A combine machine for soil ridging and sowing maize grains on the suitable ridge side was developed. The developed machine was manufactured in a local workshop by using local rough material in El-Kordy city - Dakahlia governorate Egypt. The developed machine dimensions were $97 \mathrm{~cm}$ in height and 176 $\mathrm{cm}$ in width and its components mainly as following details :- 
- The machine frame:- It was manufactured from iron bars with square cross section $(10 \times 10 \mathrm{~cm})$. The frame has rectangular shape with $176 \mathrm{~cm}$ length and $140 \mathrm{~cm}$ width. The machine frame has three hitch points in its front, and it provides also with two wheels which provide the machine feeding system with rotating motion.

- The sowing unit:- It has two sowing units, every unit exclusive for sowing maize grains in one ridge. Every planting unit consisting of the following details:-

(a)- The grains hopper: - It has a cylindrical shape with $27 \mathrm{~cm}$ diameter and $40 \mathrm{~cm}$ height. The grains hopper provides with two disks on its bottom. The first was a feeding disk which has many holes distributed around its circumference, this holes named (Feeding cells). The feeding disk take rotating motion from machine land wheel. The second disk has two holes on its circumference. This disks provide with two pins passing from hopper wall through two holes in the hopper lower, and attached with two ropes. The Tractor driver catch the other end of the ropes. The driver can be regulate planting grains in the suitable ridge side by tauten one of this ropes in the end of every pass.

(b) The rubber tube and the sowing depth regulator:- The grains hopper bottom provided with two holes, every one attached with rubber tube to carry out sowing grains to suitable sowing place in ridge side, the other end of the rubber tube attached with iron tube can be moved up and down on vertical scale on two ridge former sides to regulate the sowing depth. Developed machine dimensions and its specifications illustrated in fig. (3.1 and 3.2).

Ridgers:-There are three ridgers every one provide with shank attached with front of machine frame. The distance between two neighbor ridgers 70 $\mathrm{cm}$.

The ridge Former (battana):- It was fabricated from iron steel (4 mm thickness). It passed on the primary ridge which former by machine ridgers to laid sowing grains in the suitable ridge side, and reformed the soil ridge on the best form. 


\section{3-2: Instrumentations:}

- A measuring tape:-for measuring the overall distances and dimensions.

- A stop watch:- to measure the consumed time.

- A graduated cylinder:- for measuring the fuel consumption.
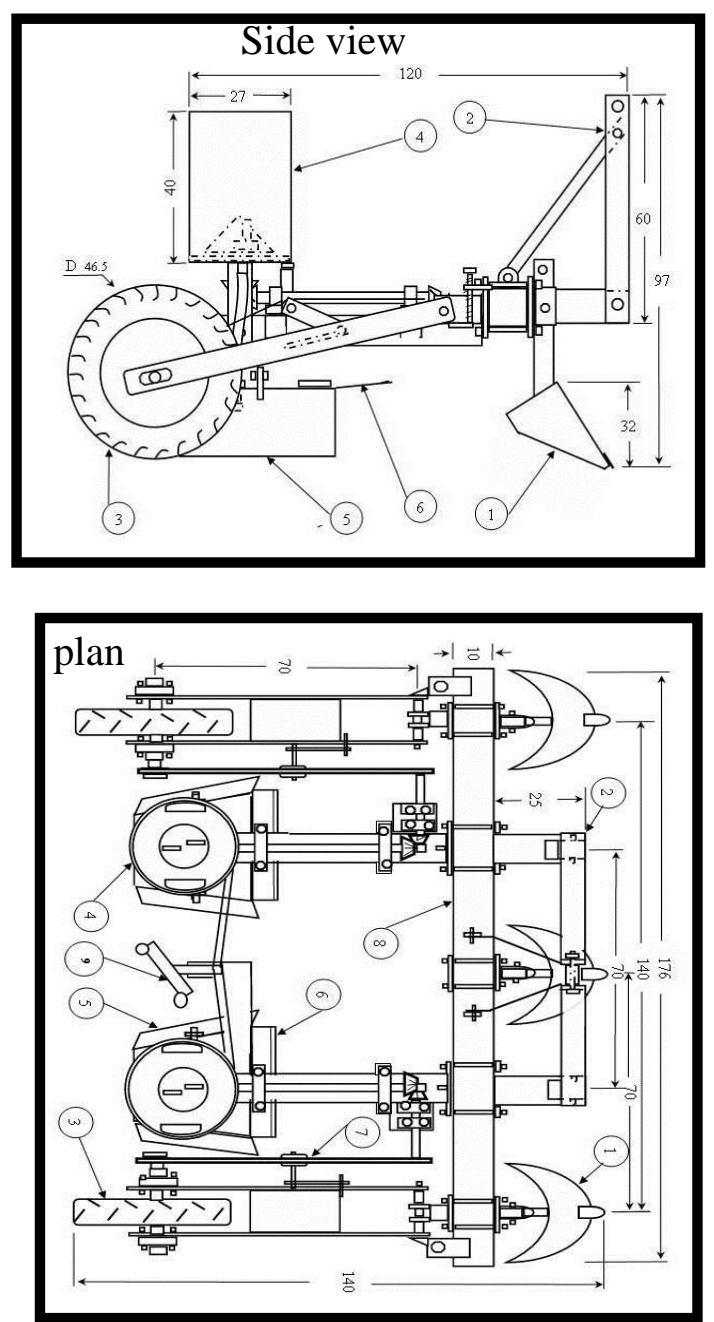

1- Ridge opener

2- Three point shank

3- Wheel

4- Planting hobber

5- Former

6- Former inlet

7- Transmission unit

8- Main frame

9- Changing arm

Fig. (3-2): The side view and plane of the Machine. 




Fig. (3-3) Photo of the Machine.

\section{3-3:Field Experiments :-}

Field experiments were carried out during 2009/2010 growing season, and it divided into two experimental group (first and second experimental groups) as mentioned before. There for the field area was about one feddan. The first experimental study was carried out on the mentioned area to select the optimum engineering parameters which gained the best ridge profile and cross section area and used this parameters in the second experimental group. Then the same area was leveled in order to create the second experimental group of study. Every experimental site divided into many plots (one plot for every experimental treatment). All the experimental treatments randomly distributed on plots to employed the obtained data as the complete randomized design.

\section{3-4: Measurements:}

3-4-1: The first experimental group :- The following equation was used to determine the obtained cross section area according to Sohne et al (1962)

$$
\mathrm{A}=\frac{\Delta L}{2}(\mathrm{a}+2 \mathrm{~b})
$$

Where:-

$\mathrm{A}=$ Total cross section area $\mathrm{cm}^{2}$

$\Delta \mathrm{L}=$ Constant horizontal distance, $\mathrm{cm}$.

$\mathrm{a}=$ Sum of first and last ordinates, $\mathrm{cm}$.

$\mathrm{b}=$ Sum of all ordinates excluding the first and last ones, $\mathrm{cm}$. 
- The sawing ridge profile was drown by laid the profile meter on a vertical position perpendicular to the sawing row direction and adjusting its wooden sticks to touch the ridge surface on lateral sector. The final height of the wooden sticks takes the same profile of the ridge surface.

The ordinates and ridge cross section profile were measured and drowned by using the profile meter shown in fig. (3-4)



Fig. (3-4) Measuring soil profile.

\section{3-4-2: The second experimental group :-}

3-4-2-1: the longitudinal scattering:- Deviation plants in the longitudinal direction from the average distance of 10 meter along the planting row, were determined after two week from planting and first irrigation by using the following equation:-

$$
\begin{aligned}
& s d=\sqrt{\frac{\sum\left(X-X^{-}\right)}{n} .} \\
& C . V=\frac{s d}{X} \times 100 \ldots \ldots \ldots . .
\end{aligned}
$$

\section{Where :}

C.V $=$ The coefficient of variation.

$\mathrm{sd}=$ Standard deviation.

$\mathrm{n}=$ Number of observation .

$\mathrm{X}=$ The mean distance between plants in 10 meters along planting row. 


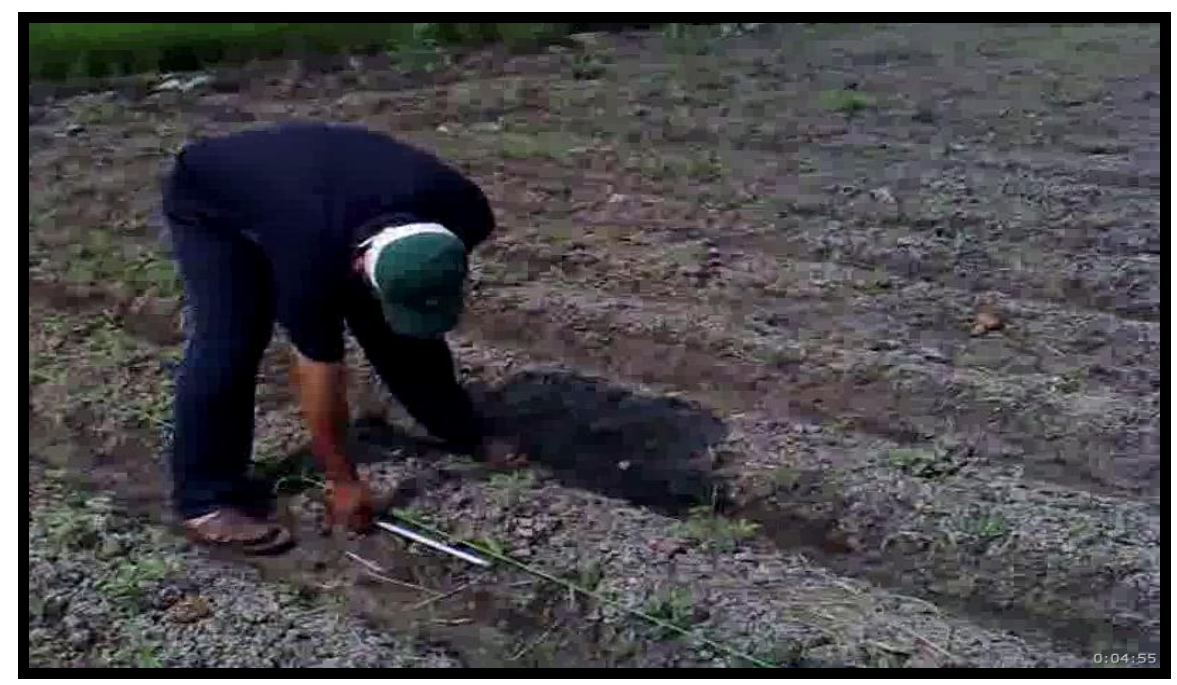

Fig. (3-5) Determining Longitudinal and lateral Scattering.

\section{3-4-2-2: Plant lateral distribution around the planting row centerline:-}

To determine the cross scattering of plants around the rows, the distribution of the plants around the row centerline was determined two weeks after sowing and irrigation. The distribution was estimated by relating the number of plants at ten meters along of the row. The frequency distribution curves were employed for expressing this relationship for each experiment.

3-4-2-3: Emergence percentage:- It was determined after two weeks from sowing by the following equation :-

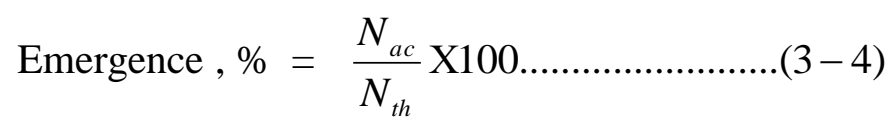

where:-

$\mathrm{Nac}=$ actual number of plants in 10 meters length.

$\mathrm{Nth}=$ theoretical number of plants in 10 meters length .

\section{RESULTS AND DISCUSSION}

This study was carried out in order to evaluate the performance of the developed machine and also to determine the best working engineering parameters, the obtained results of this study could be divided into two main groups. 
4-1: The first Experimental Group: The optimum cross section area was $\left(673.44, \mathrm{~cm}^{2}\right)$ and the optimum ridge profile was gained at opener depth $9 \mathrm{~cm}$, forward speed $0.55 \mathrm{~m} / \mathrm{sec}$, ridge former side angle 60 degree and former height $3 \mathrm{~cm}$ is illustrate in figure (4-1).



Fig. (4-1) :The Optimum Soil Profile.

4-3: The second Experimental Group: The obtained results of this study could be explained under three hills as follow:-

1- Longitudinal scattering: The longitudinal space between two plants $(22,24,26$ and $28 \mathrm{~cm})$ had indirectly proportional with coefficient of variation (C.V., \%) of actual plants longitudinal scattering. On the other side the results were showed that the highest value of (C.V., \%) was (31.68\%) obtained at the lowest theoretical space $(\mathrm{h}=22 \mathrm{~cm}$.). While the lowest value of (C.V., \%) was $(21.26 \%)$ gained at the highest theoretical space $(\mathrm{h}=28 \mathrm{~cm}$.) and the constant forward speed $(\mathrm{S}=0.55$ $\mathrm{m} / \mathrm{sec}$ ) and the multi regression equation could be calculated as follow :Longitudinal dispersion $(C . V ., \%)=35.2-2.070 h-1.24 d, \quad R^{2}=95.8 \%$

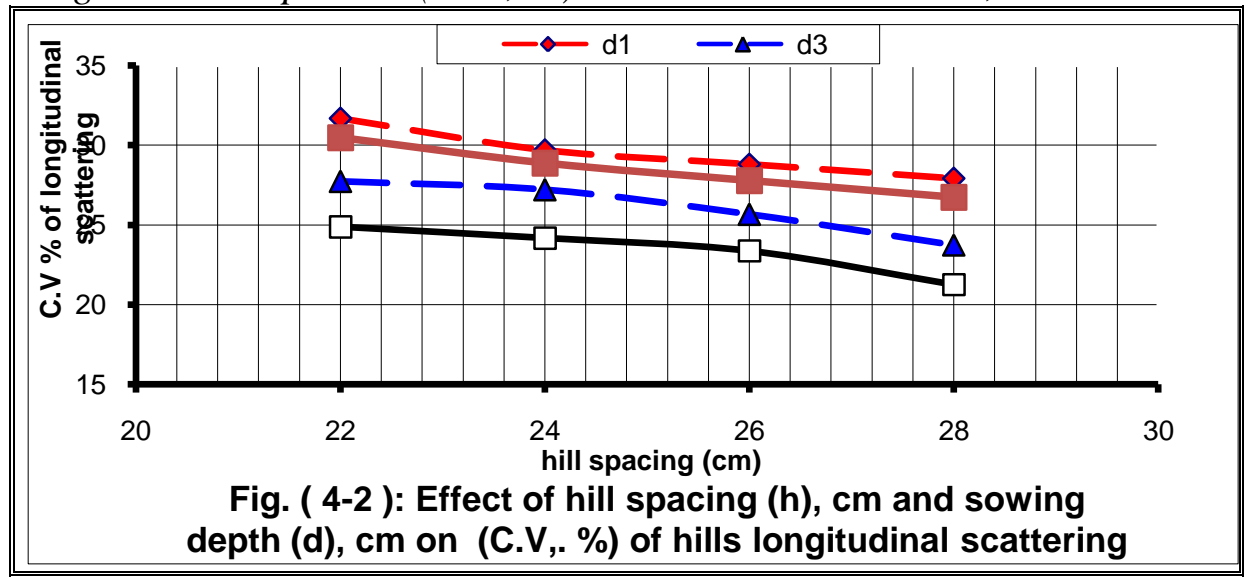


From the other side the sowing depth $(2,3,4$ and $5 \mathrm{~cm})$ had indirectly proportional with coefficient of variation (C.V., \%) of actual plants longitudinal scattering. On the other side the result were showed that the highest value of (C.V. \%) was $(31.68 \%)$ at the lowest sowing depth $(\mathrm{d}=$ $2 \mathrm{~cm}$.). for planting maize after emergence. While the lowest value of (C.V. \%) was $(21.26 \%)$ gained at the highest sowing depth $(\mathrm{d}=5 \mathrm{~cm}$.) and forward speed ( $\mathrm{s}=0.55 \mathrm{~m} / \mathrm{sec}$.).

\section{2- lateral scattering, $\%$.}

Figures from (4-3 through 4-6) show the effect of sowing depth (d) on the lateral scattering, $\%$ of Maize plants around planting row center line. These mentioned data show that increasing in sowing depth (d) tend to decrease in the lateral scattering, $\%$ in the center line of planting row .
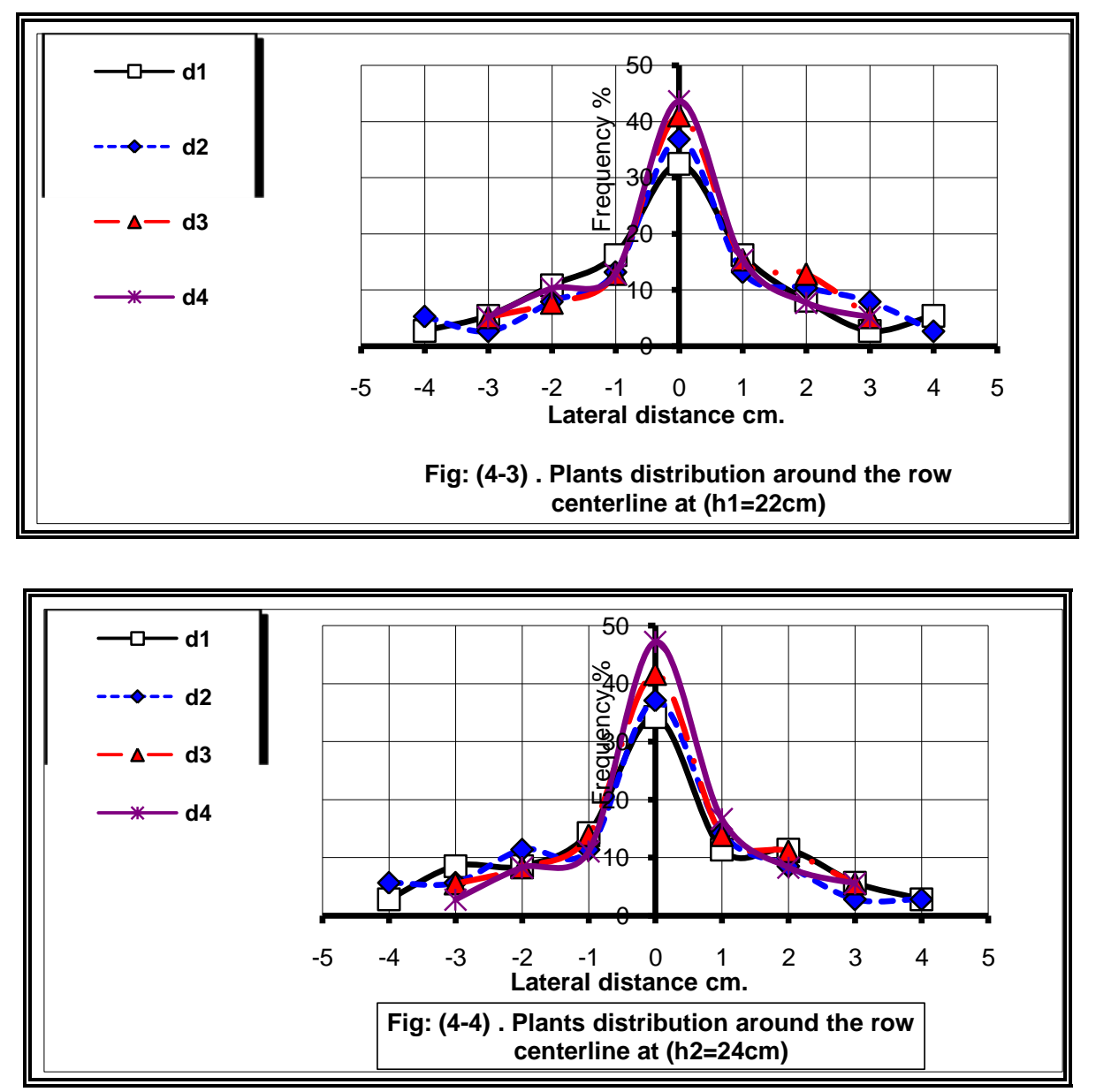


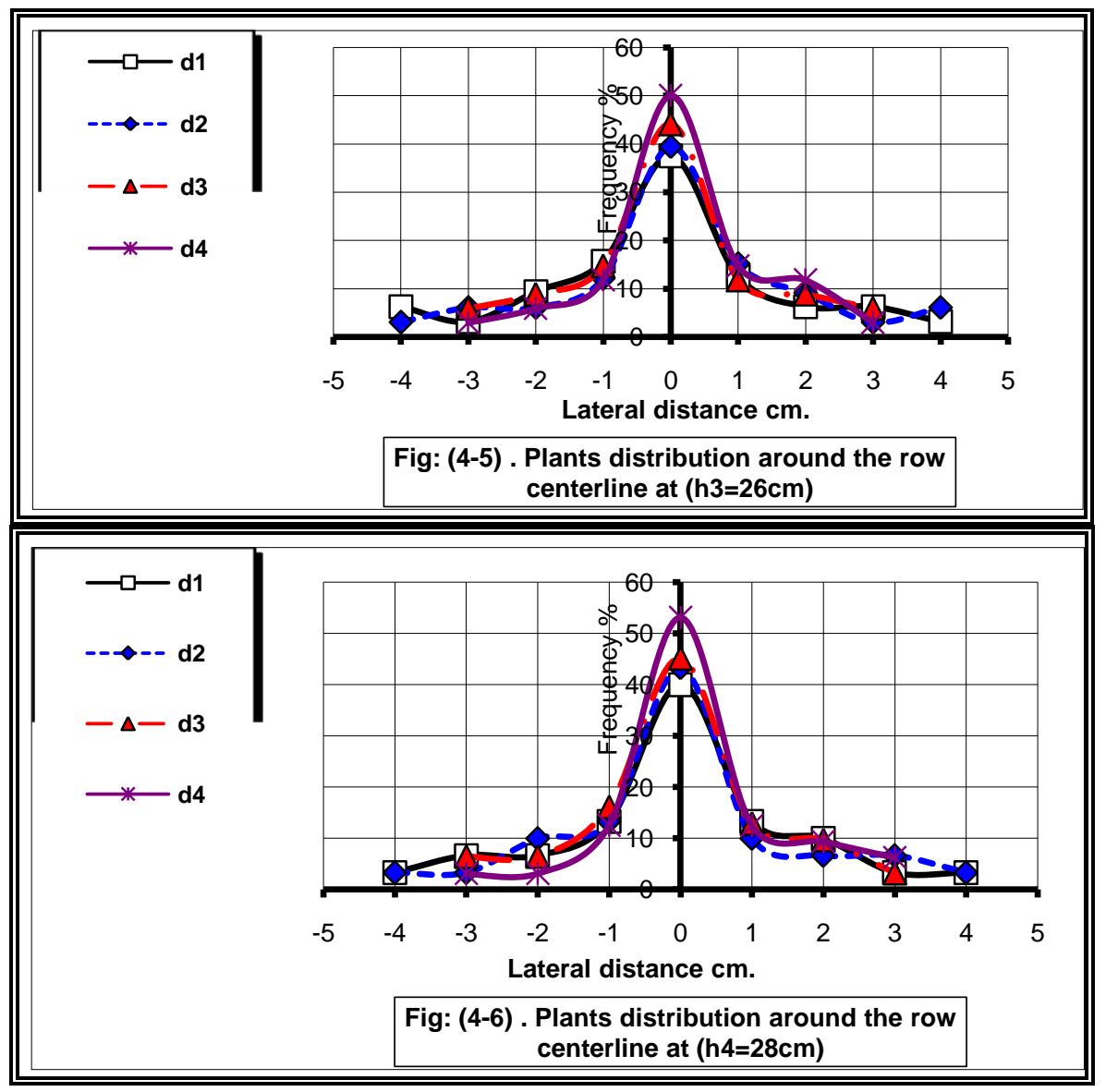

Figures from (4-7 through 4-10) show the effect of hill spacing (h) on the lateral scattering of Maize plants around planting row center line. These mentioned data show that increasing in hill spacing (h) tend to decrease in the lateral scattering, $\%$ in the center line of planting row .

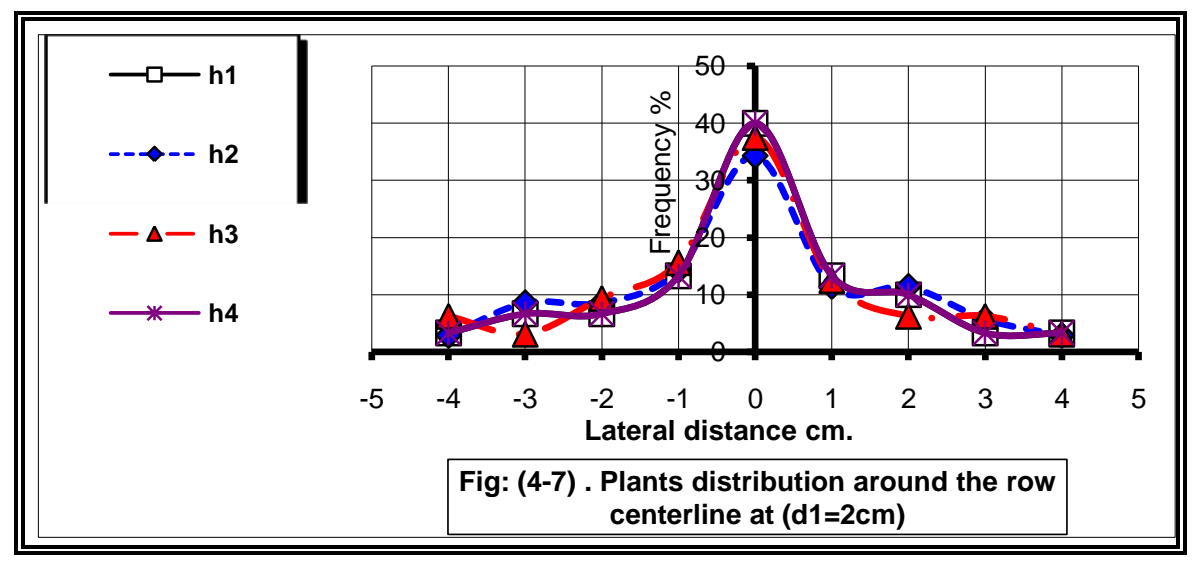



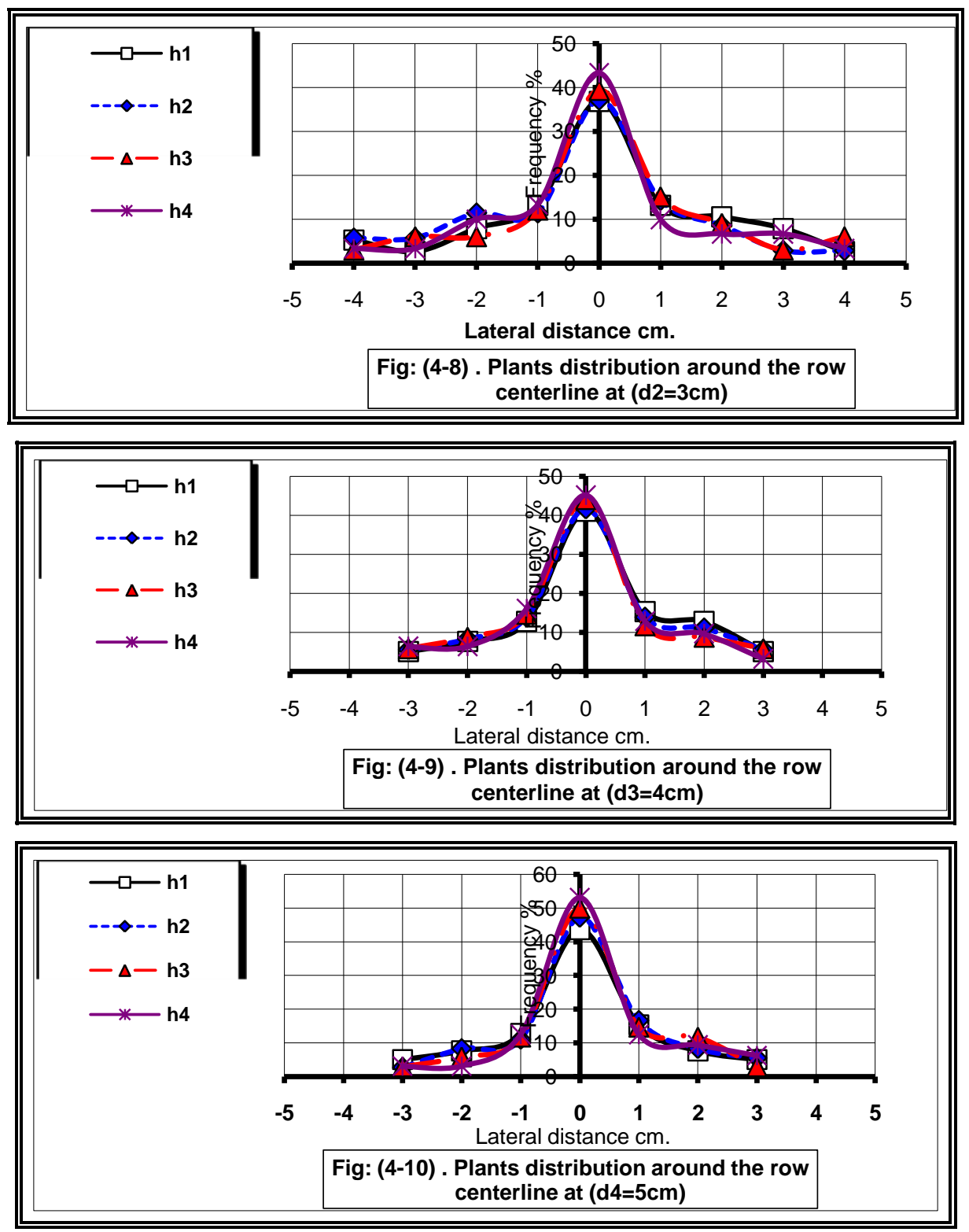

\section{3-The emergence percentage:}

Figures (4-11 and 4-12) show the effect of sowing depth and hill spacing on emergence, \%. It was remarked that emergence percentage, \% increased with increasing sowing depth and hill spacing. The relationship between germination ratio, $\%$ and each of sowing depth and hill spacing can be represented by the following regression equations:

Emergence, $\%=80.4+0.342 h+1.56 d, \quad R^{2}=94.3 \%$ 


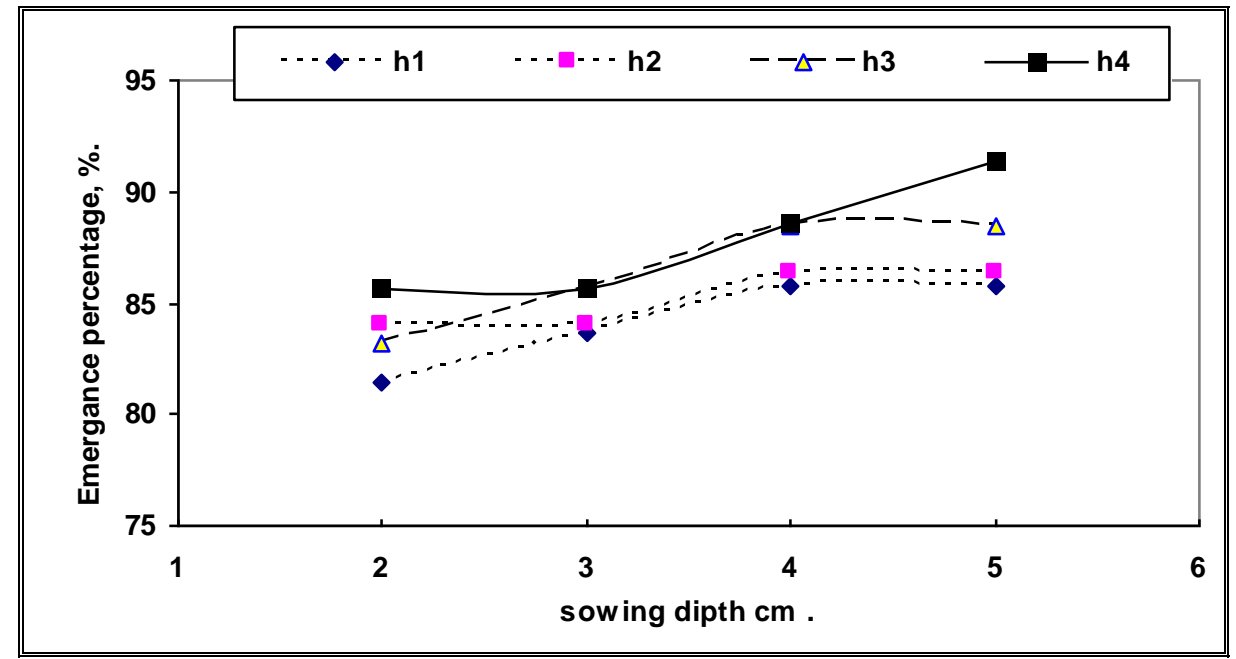

Fig. (4-11): Effect of sowing depth on emergence, \%

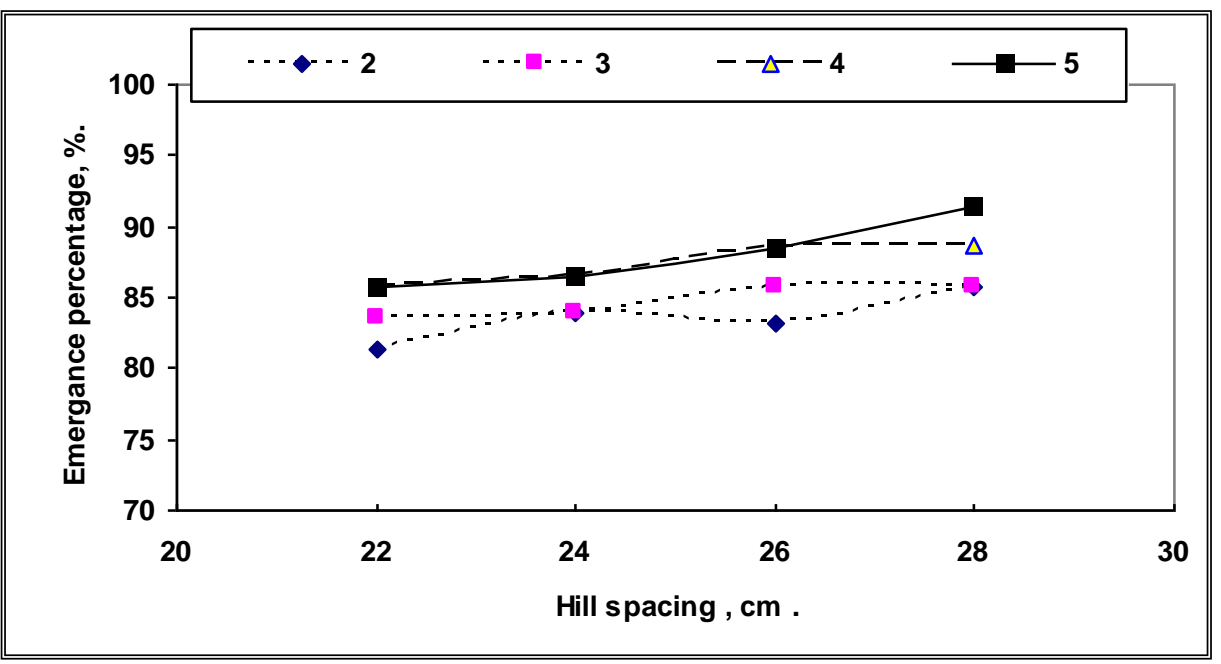

Fig. (4-12): Effect of hill spacing on emergence, $\%$.

\section{CONCLUSION}

This research was conducted to develop the combined machine to planting (zia maize) on the suitable side of ridge. the results of this study can be summurized os follow:- 
1- The optimum soil profile was optained at ( depth $9 \mathrm{~cm}$, forward speed $0.55 \mathrm{~m} / \mathrm{sec}$, angle 60 degree and height $3 \mathrm{~cm}$ ).

2- The highest cross section area $\left(673.44, \mathrm{~cm}^{2}\right)$ was gained under the lower former height $(\mathrm{H} 1=-6 \mathrm{~cm})$, Ridge former side angle $\left(\mathrm{A} 4=60^{\circ}\right)$, ridger depth $(\mathrm{D} 3=9 \mathrm{~cm})$ and tractor forward speed $(\mathrm{S} 1=0.55 \mathrm{~m} / \mathrm{sec})$.

3- The minimum value of longitudinal scattering (C.V, \%) was 21.26 was gained at planting space $28 \mathrm{~cm}$ and sowing depth $5 \mathrm{~cm}$.

4- The optimum value of transverse scattering at planting space $28 \mathrm{~cm}$ and sowing depth $5 \mathrm{~cm}$.

5- The maximum value of emergence percentage, $\%$ was 88.4 at sowing space $26 \mathrm{~cm}$ and sowing depth $5 \mathrm{~cm}$.

\section{REFERENCE}

Coates, W. (1992). Performance evaluation of a pendulum spreader. Trans. ASAE, 8(3):285-288.

Dowell, F. E., J. C. Siemens and L. E. Bode. (1988). Cultivator speed spacing effects on herbicide incorporation. Transactions of ASAE 31(5): 1315-1321.

FAO, (2010): http://faostat.fao.org/site/567/DesktopDefaults.aspx?page $\underline{\mathrm{ID}}=567,7 / 3 / 2012$.

Marey s.a. (2008) Development of planter for minimizing. row spaces and maximizing the sugar beet. misr j. ag. eng., 25(4): 1112-1130., october 2008.

Sharifat K. and R. L. Kushwaha. (1999). Lateral soil movement by tillage tools. ASAE Paper No. 991003. St. Joseph, Mich.: ASAE.

Snedecor, G. W. and W. G. Cochran (1967). Statistical Methods 6th. Ed., Ames: The Iowa State University U.S.A., Press, 593p. 
Sohne, W.R. Moller and R. Bruer (1962): Gerate and Messein- rich tungen zur Durch fuhrung und Answer tung Von Pflug Versuchen. Land Technik, Forschung, 12, H, 2 : 44- 47.

\section{الملخص العربي}

\section{الزراعة الميكانيكية على الجانب المناسب من الخط}

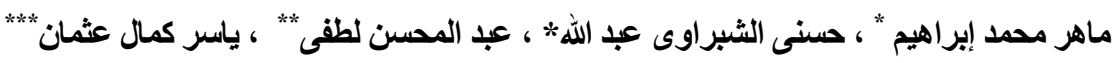
تعتبر الزر اعة الآلية على الجانب المناسب من خط الزر اعة (الريثة العمالة) من العمليات التى التى

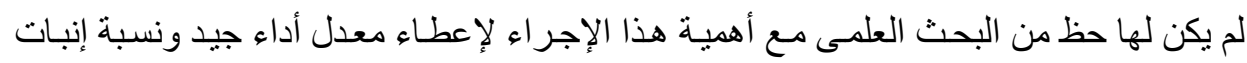

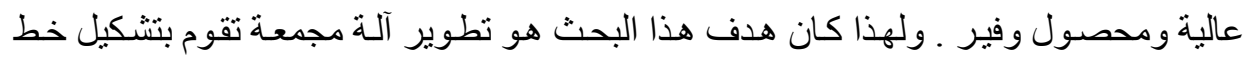
زر اعة مناسب ووضع البذور على العمق المناسب و على الجانب المطلوب من خط الزر اعة العة .

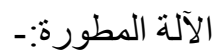

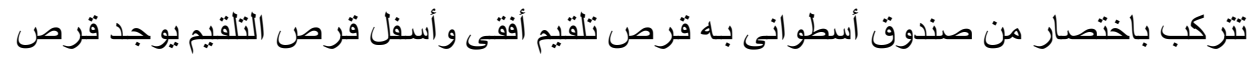



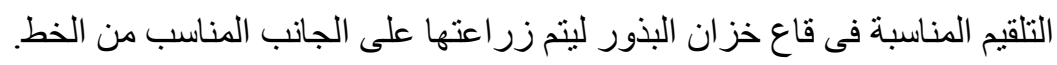

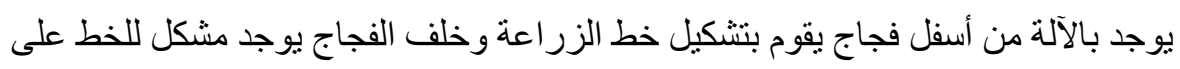
شكل بنانة لرسم وتسوية الخط المشكل. تم تقسيم البحث إلى مجمو عنين من التجارب:المجمو عة الأولى:-تمت فى الحقل على الجزء الخاص بتثكيل الخط لتحديد أنسب بروفيل خط


من التجارب : n من

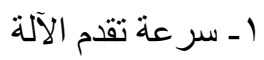


ب- م- زاوية جو انب مشكل الخط.

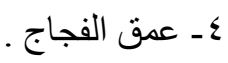

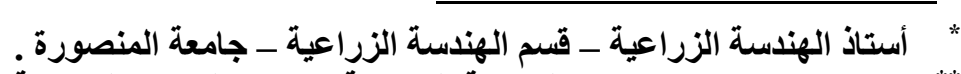

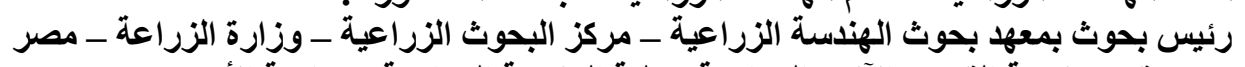

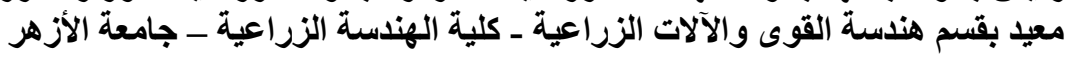


المجموعة الثانية من التجارب :- تم أخذ المستويات المثلى من عو امل الدراسة فى المجو عة

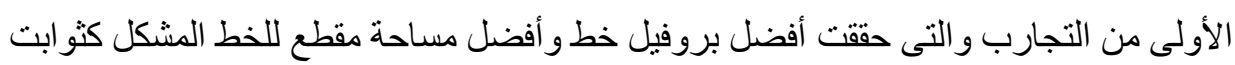
فى المجمو عة الثانية من التجارب وتم در اسة عاملين جديدين و هما :

$$
\begin{aligned}
& \text { 1- ـ مسافات الزر اعة } \\
& \text { r- عمق الزراعة. }
\end{aligned}
$$

وكانت أهم القياسات فى هذه المجمو عة من التجارب هى :1- التشتت الطولى للنباتات النامية بعد الزر اعة

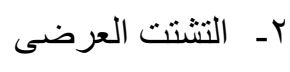

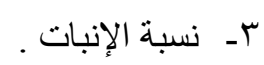

وقد تحقق أقل تشتت طولى عند معاملات در اسة (مسافة زر اعة ب سم ، و عمق زر اعة هسم). وتحقق أقل تثتت عرضى عند معاملات در اسة (مسافة زر اعة \^ سم ، و عمق زر اعة هسم). وتحقق أعلى نسبة إنبات عند معاملات در اسة (مسافة زر اعة \\ سم ، و عمق زر اعة هسم). 